\title{
A Literature Review: Stress Management in The Family of Intensive Care Patients
}

\author{
Gusti Pandi Liputo, Nissa Aruming Silla, Zulfainda Eka PU, Zaenal Abidin, Alwan Revai, Ah Yusuf \\ Fakultas Keperawatan \\ Universitas Airlangga \\ Email*: gusti@ung.ac.id
}

\begin{abstract}
Introduction: Intensive care unit is a unit with a complex case and a stressor strainer. When patients enter intensive care families have a variety of stressors such as rapid decision making and costs are not small. The role of nurse as educator is very important in reducing family anxiety with patients treated in intesive units. Mothers of intensive care babies feel a great deal of anxiety over their child's condition, so there needs to be a good system support for the healing of her and her baby. Various ways nurses do in reducing stress experienced by the patient's family such as good communication between nurses and families of patients with intensive care. This review aims to get a picture of stress management that can be done on the family of intensive care patients. Methods: A literature review was conducted in the fields of ebscho, sience direct, elseiver, sage journals, scopus, and proquest, limited the range of the last 10 years from 2007-2017. The final sample included 18 articles. Results: The literature found that the causes of family stressors include rapid decision-making, fear of family emergency conditions, maintenance costs and length of care. Good communication and good information and skill support can decrease the stress experienced by intensive care patients' families. Conclussions: Intensive care is a unit with high complexity, unstable conditions and sophisticated technology. Conditions that require rigorous monitoring not only cause stressors for the patient, but become a stressor for the patient's family.
\end{abstract}

Keyword: Intensive Care, Stress Management, Family Nursing.

\section{INTRODUCTION}

Intensive care is a core component of comprehensive care for patients facing critical illness, regardless of age, diagnosis, or prognosis. The main domains of the intensive care unit include relieving perceived symptoms, effective communication of care goals, patient or family-focused decisionmaking, nearest outreach support, and continuity of care (Noome et al., 2016). Entrance ICU may be abrupt and unexpected, ICU complex environment is foreign and frightening, and can be considered as inhuman or burdensome. The sad psychological symptoms among the families of ICU patients are most common during critical illness and decline over time (Wintermannet al., 2016). Fifty percent of US hospital deaths occur during or after living in an intensive care unit (ICU), family members must make this difficult decision on behalf of their loved ones. While doing so, they may worry that one of their loved ones has suffered or that they have given up too soon, and two thirds of ICU death (Bloomer et al., 2013).

Intensive patient-family stress has been the main theme of numerous studies in the field of health psychology in recent years, the family stress incidence from various studies of the world varies considerably between $25 \%$ and $87 \%$ (Jongerden et al., 2013). This is reinforced by research conducted by (Turner et al., 2015) as many as $54.3 \%$ of families without direct blood relation stress and $75.7 \%$ of families with blood relations experience anxiety.

Various ways have been done to reduce anxiety in families of ICU patients and nurses have an important role in the process (Mitchell and Courtney, 2004). The nurse is the health worker who has the most interaction time with the patient's family, the nurse knows with certainty the stress experienced by the 
patient's family so that the nurse can also provide support to the patient's family (Jongerden et al., 2013).

The purpose of this study is to conduct a literature review on stress management in the family of intensive care patients. In this study,

\section{METHODS}

A literature search was conducted in the fields of ebscho, science direct, elsevier, sage journal, scopus and proquest. The term care was searched in combination with following key words: "Stress Management" AND Family AND Intensive Care.The search resulted in 183 citations. During this process, 129citation were excluded due to the title not being relevant. The 54 citation which were the authors identified the stress management publication journal on intensive care family families. The results of this review literature are expected to be applied to health services especially nursing.

found relevant were retrieved for detailed evaluation. The titles and/or abstracts of these 26 article were read again by the authors. This process resulted in 21 articles, a further 3 were excluded because they did not discuss family stress in icu. The final sample included 18 articles.

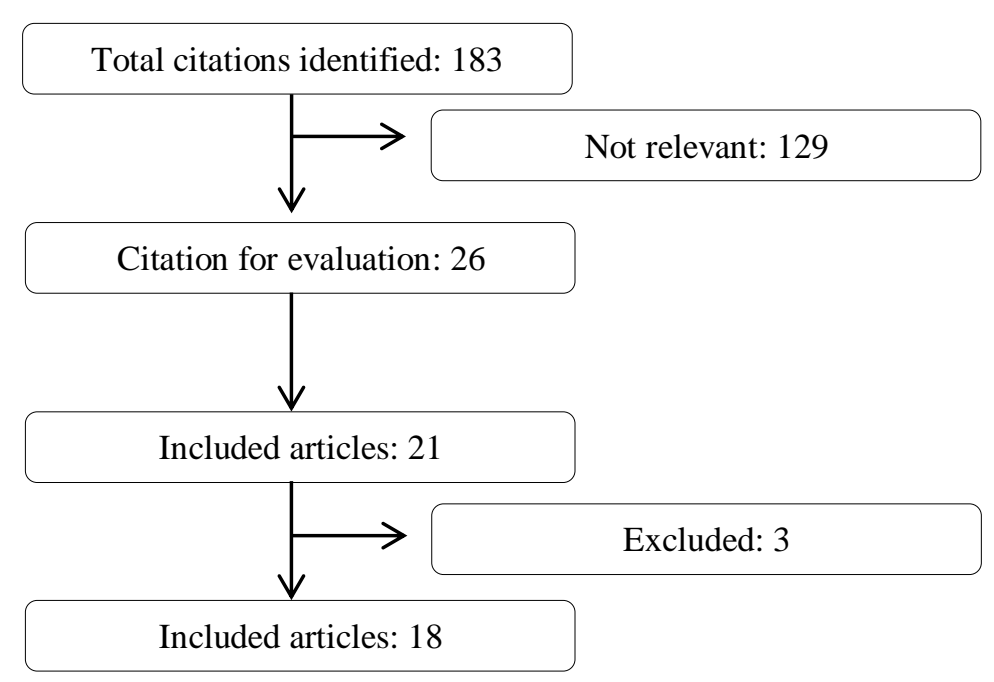

Figure1: Literature identification process

\section{RESULTS}

The review literature process of 18 journals obtained by the authors found 16 variable factors that influence the occurrence of stress in the family of intensive care patients. There are four dominant factors that influence the stress on the family of intensive care patients, namely rapid decision making, cost and length of care, risk of death threatening, and sudden change of condition.
Several methods have been undertaken to deal with stress that occurs in the patient's family such as good communication, support and empathy, as well as providing good information as a basis for decision making. Good nurse skills also affect the patient's family stress level. 
Table 1: Mapping research

\begin{tabular}{|c|c|c|c|}
\hline Title and author & Variable & Design & Results \\
\hline $\begin{array}{l}\text { Care and caring in the } \\
\text { intensive care unit: } \\
\text { Family members' } \\
\text { distress and } \\
\text { perceptions about staff } \\
\text { skills, communication, } \\
\text { and emotional support } \\
\text { (Carlson } \text { et al., 2015) }\end{array}$ & $\begin{array}{l}\text { Family members' } \\
\text { distress and } \\
\text { Perceptions }\end{array}$ & $\begin{array}{l}\text { cross-sectional } \\
\text { descriptive survey }\end{array}$ & $\begin{array}{l}\text { The competency and skills of staff } \\
\text { are much higher than the value of } \\
\text { communication frequency, } \\
\text { information needs, and support. } \\
\text { The frequency of communication } \\
\text { and the information needs met are } \\
\text { strongly related to the support value } \\
\text { (rs }=0.75 \text { to } 0.77 \text { ) and the staff } \\
\text { skills (rs }=.77-.85 \text { ), and the } \\
\text { satisfaction and communication } \\
\text { aspects show a negative } \\
\text { relationship with gejaladepression } \\
\text { (rs =.31 to -55) and PTSD (rs =-17 } \\
\text { to -43) }\end{array}$ \\
\hline
\end{tabular}

\begin{tabular}{llrl}
\hline Nursing strategies to & Nursing & strategies to & a prospective, \\
support family & support & family & qualitative descriptive \\
members of ICU & members & & study
\end{tabular}
Family members describe five

patients at high risk of dying (Adams et al., 2014)

\section{nursing approaches: Showing} concern, building rapport, showing professionalism, providing factual information, and supporting decision making. This study provides evidence that when using this approach, nurses help family members to address the problem; to have hope, confidence, and trust; to prepare and receive the coming death; and to make decisions

Supporting families in anxiety, and the ICU: A descriptive correlational study of satisfaction with care cross-sectional descriptive

The mean information support, judged by the modified version of CCFNI (Molter and Leske, 1983), correlational is $55.41 \quad(\mathrm{SD}=13.28$; the theoretical range 20-80). The mean anxiety, judged by State Anxiety Scale (Spielberger et al., 1983) was 45.41 ( $\mathrm{SD}=15.27$, the theoretical range 20-80). The mean satisfaction with treatment, assessed using AndrofactTM (Version 4.0, 2001), was 83.09

$(\mathrm{SD}=15.49$; the theoretical range 24-96). A significant positive correlation was found between information support and satisfaction with care $(r=0.741, \mathrm{p}$ $<.001)$. There is no significant relationship between information support and anxiety or between satisfaction with care and anxiety

\begin{tabular}{llll}
\hline $\begin{array}{l}\text { Symptoms of anxiety } \\
\text { and depression in } \\
\text { family members of }\end{array}$ & $\begin{array}{l}\text { Anxiety } \\
\text { Depression }\end{array}$ & $\begin{array}{l}\text { A prospective } \\
\text { multicenter study }\end{array}$ & $\begin{array}{l}\text { Symptoms of anxiety and } \\
\text { depression were found in } 73.4 \% \\
\text { and } 35.3 \% \text { of family members; }\end{array}$ \\
intensive care unit & & $75.5 \%$ of family members and \\
patients before & & $82.7 \%$ of couples had symptoms of \\
discharge or death & & & anxiety or depression $(\mathrm{P}=0.007)$
\end{tabular}




\begin{tabular}{|c|c|c|c|}
\hline & & & $\begin{array}{l}\text { Factors associated with symptoms } \\
\text { of anxiety and depression: } \\
\text { 1. Relationship with patient: } \\
\text { severity } \\
\text { 2. Family relationship } \\
\text { 3. Neighborhood room with more } \\
\text { than } 1 \text { bed }\end{array}$ \\
\hline $\begin{array}{l}\text { Passive decision- } \\
\text { making preference is } \\
\text { associated with } \\
\text { anxiety and } \\
\text { depression in relatives } \\
\text { of patients in the } \\
\text { intensive care unit } \\
\text { (Anderson, Arnold } \\
\text { and Angus, 2009) }\end{array}$ & $\begin{array}{l}\text { Anxiety } \\
\text { Depression }\end{array}$ & $\begin{array}{l}\text { observational pilot } \\
\text { study }\end{array}$ & $\begin{array}{l}12(25 \%) \text { preferred active roles, } 28 \\
(58 \%) \text { preferred to share } \\
\text { responsibility with physicians, and } \\
8(17 \%) \text { preferred passive roles. Of } \\
\text { the } 50 \text { relatives, } 21 \text { (42\%) had } \\
\text { anxiety symptoms, and } 8(16 \%) \\
\text { had symptoms of depression. In } \\
\text { groups that favored the active role, } \\
\text { joint role, and passive role, } \\
\text { respectively, anxiety levels were } \\
42 \%, 25 \% \text {, and } 88 \%(\mathrm{P}=0.007) \text {, } \\
\text { and depression rates were } 8 \% \text {, } \\
11 \% \text {, and } 50 \% \text { (P }=.026) \text {. } \\
\text { Relatives who prefer the role of } \\
\text { passive decision making are the } \\
\text { most likely to be anxious and } \\
\text { depressed. }\end{array}$ \\
\hline $\begin{array}{l}\text { Supporting families in } \\
\text { the ICU: A descriptive } \\
\text { correlational study of } \\
\text { informational support, } \\
\text { anxiety, and } \\
\text { satisfaction with care. } \\
\text { (Bailey et al., 2010) }\end{array}$ & $\begin{array}{l}\text { informational support } \\
\text { anxiety } \\
\text { satisfaction with care }\end{array}$ & $\begin{array}{l}\text { cross-sectional } \\
\text { descriptive } \\
\text { correlational pilot } \\
\text { study }\end{array}$ & $\begin{array}{l}\text { A significant positive relationship } \\
\text { was found between information } \\
\text { support and satisfaction with care ( } \mathrm{r} \\
=0.741, \mathrm{p}<.001) \text {. No significant } \\
\text { relationship was recorded between } \\
\text { information support and anxiety or } \\
\text { between satisfaction and treatment } \\
\text { Anxiety }\end{array}$ \\
\hline $\begin{array}{l}\text { Effectiveness of } \\
\text { nursing interventions } \\
\text { based on family needs } \\
\text { on family satisfaction } \\
\text { in the neurosurgery } \\
\text { intensive care unit } \\
\text { (Yousefi et al., 2012) }\end{array}$ & $\begin{array}{llr}\text { Nursing } & \text { interventions } \\
\text { based } & \text { on family } \\
\text { needs. } & & \end{array}$ & $\begin{array}{l}\text { randomized } \\
\text { controlled trial }\end{array}$ & $\begin{array}{l}\text { 1. There was no significant } \\
\text { difference in mean satisfaction } \\
\text { scores between the test group } \\
\text { and the control group prior to } \\
\text { the intervention. } \\
\text { 2. The average satisfaction score } \\
\text { increased significantly after the } \\
\text { intervention compared with the } \\
\text { control group. } \\
\text { 3. Nursing orders based on family } \\
\text { needs of inpatients in ICU } \\
\text { improve their satisfaction. } \\
\text { Attention to family nursing } \\
\text { should be planned especially in } \\
\text { ICU. }\end{array}$ \\
\hline $\begin{array}{l}\text { Development and } \\
\text { usability testing of a } \\
\text { Web-based decision } \\
\text { aid for families of } \\
\text { patients receiving } \\
\text { prolonged mechanical } \\
\text { ventilation } \\
\text { (Cox et al., 2015) }\end{array}$ & Surrogate decision & A Pilot Study & $\begin{array}{l}\text { 1. Provide a framework for } \\
\text { sharing decision-making, } \\
\text { generating relevant values and } \\
\text { preferences } \\
\text { 2. Incorporating clinical data to } \\
\text { personalize prognostic } \\
\text { estimates } \\
\text { 3. Produce printable documents } \\
\text { that encapsulate user interaction } \\
\text { with decision help, and can } \\
\text { digitally archive individual user } \\
\text { sessions. } \\
\text { 4. The usefulness is very good }\end{array}$ \\
\hline
\end{tabular}


(mean SUS, $80 \pm 10$ ) overall, but lower among those aged 56 years and over $(73 \pm 7)$ than those younger $(84 \pm 9) ; \mathrm{p}=$ 0.03 .

5. It is a strategy that can improve patient-clinic collaboration and quality decision-making in intensive care

\begin{tabular}{|c|c|c|c|}
\hline $\begin{array}{l}\text { The Assesment of } \\
\text { Parental stress and } \\
\text { support in the } \\
\text { neonatal intensive } \\
\text { care unit using the } \\
\text { parent stress scale - } \\
\text { Neonatal Intensive } \\
\text { Care Unit (Turner et } \\
\text { al., 2015) }\end{array}$ & $\begin{array}{lcr}\text { Parental } & \text { stress } & \text { and } \\
\text { support } & \text { in the } \\
\text { neonatal } & \text { intensive } \\
\text { care unit } & & \end{array}$ & Case Study & $\begin{array}{l}\text { Assessment of the strees needs to } \\
\text { be done to provide emotional } \\
\text { support to the patient's family, in } \\
\text { addition to providing accurate and } \\
\text { accurate information to minimize } \\
\text { stress in the family. P value: } 0.001\end{array}$ \\
\hline $\begin{array}{l}\text { Does time of transfer } \\
\text { from critical care to he } \\
\text { general wards affect } \\
\text { anxiety? A pragmatic } \\
\text { Prospective cohort } \\
\text { study (McCairn and } \\
\text { Jones, 2014) }\end{array}$ & $\begin{array}{l}\text { time of transfer from } \\
\text { critical care to he } \\
\text { general wards affect } \\
\text { anxiety }\end{array}$ & Cohort Study & $\begin{array}{l}\text { Displacement of patients from } \\
\text { intensive care to common room } \\
\text { care performed at night can } \\
\text { increase anxiety and stressors in the } \\
\text { family. }\end{array}$ \\
\hline $\begin{array}{l}\text { The effect of a family } \\
\text { support intervention } \\
\text { on family satisfaction, } \\
\text { length-of-stay, and } \\
\text { cost of care in the } \\
\text { intensive care unit } \\
\text { (Shelton } \text { et al., 2010) }\end{array}$ & $\begin{array}{lcc}\text { a } & \text { family } & \text { support } \\
\text { intervention } & \end{array}$ & Quasy Experiments & $\begin{array}{l}\text { Provision of education information } \\
\text { about the patient's condition, } \\
\text { financing and estimation of the } \\
\text { length of care done by the experts } \\
\text { in the field of psychology can } \\
\text { increase patient family satisfaction } \\
\text { and can reduce the level of stress } \\
\text { experienced by the family. }\end{array}$ \\
\hline $\begin{array}{l}\text { Reducing family } \\
\text { members' anxiety and } \\
\text { uncertainty in illness } \\
\text { around transfer from } \\
\text { intensive care: an } \\
\text { intervention study } \\
\text { (Mitchell and } \\
\text { Courtney, 2004) }\end{array}$ & $\begin{array}{l}\text { Reducing family } \\
\text { members' anxiety }\end{array}$ & $\begin{array}{l}\text { Pre test }- \text { Post } \\
\text { testgrup design }\end{array}$ & $\begin{array}{l}\text { There was a decrease in the level of } \\
\text { strees and anxiety of the family, } \\
\text { with a decrease in the number of } \\
\text { families waiting / escorting from } \\
\text { the ICU chamber to the general } \\
\text { treatment room with P: } 0.002\end{array}$ \\
\hline $\begin{array}{l}\text { Nursing Interventions } \\
\text { to Reduce Stress in } \\
\text { Parents } \\
\text { Hospitalized Preterm } \\
\text { Infants (Guo, East and } \\
\text { Arthur, 2012) }\end{array}$ & $\begin{array}{l}\text { Nursing Interventions } \\
\text { to Reduce Stress }\end{array}$ & Quasy Experiments & $\begin{array}{l}\text { The nurse provides educational } \\
\text { information to the family about the } \\
\text { state of the patient, the role of the } \\
\text { family in preterm infant care, the } \\
\text { information is given whenever shift } \\
\text { change can decrease the natural } \\
\text { anxiety and stress } 8 \text { family. }\end{array}$ \\
\hline $\begin{array}{l}\text { A family nursing } \\
\text { educational } \\
\text { intervention supports } \\
\text { nurses and families in } \\
\text { an adult intensive care } \\
\text { unit (Eggenberger and } \\
\text { Sanders, 2016) }\end{array}$ & $\begin{array}{l}\text { nursing educational } \\
\text { intervention supports } \\
\text { nurses and families }\end{array}$ & Pilot study & $\begin{array}{l}\text { From the results of this study found } \\
\text { that education by nurses to the } \\
\text { family impact on the family coping } \\
\text { of patients who are disturbed due to } \\
\text { treatment experienced by patients. } \\
\text { So the need for education by nurses } \\
\text { is needed by the family to } \\
\text { overcome the problem coping } \\
\text { experienced }\end{array}$ \\
\hline $\begin{array}{lr}\text { Patient, } & \text { family- } \\
\text { centered } & \text { care } \\
\text { interventions } & \text { within }\end{array}$ & centered care & Systematic review & $\begin{array}{l}\text { PPFC involves interprofesional (all } \\
\text { health workers). PPFC itself can be } \\
\text { used by patients and families }\end{array}$ \\
\hline
\end{tabular}


the adult ICU setting:

An integrative review

(Mitchell et al., 2016) related problems facing patients. Of

the 48 articles discussed in this journal found that PFCC can improve patient cure and is recommended to be applicable in ICU

Nursing care of the
family before and
after a death in the
ICU-An exploratory
pilot study (Bloomer
et al., 2013)

Pilot study

Discovering that involves the family in the healing process of the patient. The nurse provides patientrelated information that can help the family to make decisions well and appropriately. And nurses can help meet emotional support and comfort for the family.

Exploring family family experiences Phenomenology
experiences of nursing aspects of end-of-life care in the ICU: A qualitative study (Noome et al., 2016)

Nursing care $\quad$ Pilot study

It found that most families have contributed to the end-of-life care of the patient, especially supportive care. Families express care support is very important, especially they are willing to answer questions from family and invite family to participate in care

A family intervention Family intervention $\quad$ RCT $\quad$ Family members can play an to reduce delirium in hospitalised ICU patients: A feasibility randomised controlled trial (Mitchell et al., 2017)

important role in preventing and
reducing the development of
delirium in Intensive Care Unit
(ICU) patients. Family members
are seen as important partners of
care, and their involvement gives
many positive results for ICU
patients and for themselves.
However, doctors should note that
the family is also the focus of care,
in addition to the patient, and any
involvement should occur at the
level / frequency most appropriate
for family members and, moreover,
have no adverse impact on them or
their relationship to the patient.

\section{DISCUSSIONS}

In the results of the above review found 4 dominant factors that affect the occurrence of stress in the family of intensive care patients are fast decision-making, cost and length of care, the risk of death that threatens, and changes in sudden conditions.

Decision-making at risk and within a short time is a separate stressor for the patient's family, improper decision-making can lead to deterioration of the patient's condition (Azoulay, Chaize and Kentish-Barnes, 2014). Families are sometimes confronted with difficult choices related to the condition of the patient, the intensive patient decision-making is in the family due to the inability of the patient to make a choice (Noome et al., 2016).

Intensive unit is a service with high technology and complicated procedures, the cost of the patient is not in small amounts. Special actions and equipment make costly expenses expensive (Shelton et al., 2010).

Intensive care requires extra monitoring because the patient's condition is unstable and may change in worse conditions over a short period of time, it also becomes a stress for the patient's family due to fear of death or worse conditions (Creutzfeldt et al., 2017 ). Limited family access to patient 
conditions and poor communication from healthcare providers add stressors to families (Edwards, Voigt and Nelson, 2017)

Nurses as holistic service providers in patients including family, family stressor is a separate problem that must be overcome, from the literature review conducted got some methods that can be used in stress management family of intensive patients.

Skill of the nurse is one of the things that can increase or decrease patient's family's anxiety (Anderson, Arnold and Angus, 2009). A qualified, well-nurtured nurse will foster family trust in the nurse and assure the family that the patient is in the right hands.

Good communication by means of correct delivery will make a better family response and reduce anxiety in the patient's condition (Schubart et al., 2015). The patient's family wants as much information as possible about the condition and treatment process that is given to the patient, whereas in the intensive care the access to information is not very good due to the needs of the patients who require very strict monitoring (Azoulay, Chaize and Kentish-Barnes, 2014).

Support and empathy provided by the nurse can increase optimism and tranquility for the patient's family, the family feels that the patient will be carried out well because the nurse knows exactly what the patient needs (Wetzig and Mitchell, 2017).

\section{CONCLUSSIONS}

Intensive care is a unit with high complexity, unstable conditions and sophisticated technology. Conditions that require rigorous monitoring not only cause stressors for the patient, but become a stressor for the patient's family. Through this Review Literature, the author tries to identify the appropriate stress management and can be applied to intensive patient families. After knowing stress management for family of intensive care patient is expected to be a reference in handling stress that happened to family and can be applied in health service.

\section{REFERENCES}

Adams, J. A. et al. (2014) 'Nursing strategies to support family members of ICU patients at high risk of dying', Heart \& Lung: The Journal of Acute and Critical Care. Elsevier Inc, 43(5), pp. 406-415. doi: 10.1016/j.hrtlng.2014.02.001.

Anderson, Arnold and Angus (2009) 'Passive decision-making preference is associated with anxiety and depression in relatives of patients in the intensive care unit', Journal of Critical Care, 24(2), pp. 249-254. doi: 10.1016/j.jcrc.2007.12.010.

Azoulay, E., Chaize, M. and Kentish-Barnes, N. (2014) 'Involvement of ICU families in decisions: fine-tuning the partnership.', Annals of intensive care, 4, p. 37. doi: 10.1186/s13613-014-0037-5.

Bailey, J. J. et al. (2010) 'Supporting families in the ICU: A descriptive correlational study of informational support, anxiety, and satisfaction with care', Intensive and Critical Care Nursing. Elsevier Ltd, 26(2), pp. 114-122. doi: 10.1016/j.iccn.2009.12.006.

Bloomer, M. J. et al. (2013) 'Nursing care of the family before and after a death in the ICU-An exploratory pilot study', Australian Critical Care. Australian College of Critical Care Nurses Ltd, 26(1), pp. 23-28. doi: 10.1016/j.aucc.2012.01.001.

Carlson, E. B. et al. (2015) 'Care and caring in the intensive care unit: Family members' distress and perceptions about staff skills, communication, and emotional support', Journal of Critical Care. Elsevier B.V., 30(3), pp. 557-561. doi: 10.1016/j.jcrc.2015.01.012.

Cox, C. E. et al. (2015) 'Development and usability testing of a Web-based decision aid for families of patients receiving prolonged mechanical ventilation', Annals of Intensive Care. doi: 10.1186/s13613015-0045-0.

Creutzfeldt, C. J. et al. (2017) 'Palliative Care Needs Assessment in the Neuro-ICU: Effect on Family', Neurocritical Care. Springer US, 27(2), pp. 163-172. doi: 10.1007/s12028-017-0426-3.

Edwards, J. D., Voigt, L. P. and Nelson, J. E. (2017) 'Ten key points about ICU palliative care', Intensive Care Medicine. Springer Berlin Heidelberg, 43(1), pp. 8385. doi: 10.1007/s00134-016-4481-6. 
Eggenberger, S. K. and Sanders, M. (2016) 'A family nursing educational intervention supports nurses and families in an adult intensive care unit', Australian Critical Care, 29(4), pp. 217-223. doi: 10.1016/j.aucc.2016.09.002.

Guo, P., East, L. and Arthur, A. (2012) 'A preoperative education intervention to reduce anxiety and improve recovery among Chinese cardiac patients: A randomized controlled trial', International Journal of Nursing Studies. Elsevier Ltd, 49(2), pp. 129-137. doi: 10.1016/j.ijnurstu.2011.08.008.

Jongerden, I. P. et al. (2013) 'Effect of intensive care environment on family and patient satisfaction: A before-after study', Intensive Care Medicine, 39(9), pp. 16261634. doi: 10.1007/s00134-013-2966-0.

McCairn, A. J. and Jones, C. (2014) 'Does time of transfer from critical care to the general wards affect anxiety? A pragmatic prospective cohort study', Intensive and Critical Care Nursing. Elsevier Ltd, 30(4), pp. 219-225. doi: 10.1016/j.iccn.2013.12.004.

Mitchell, M. L. et al. (2016) 'Patient, familycentred care interventions within the adult ICU setting: An integrative review', Australian Critical Care, 29(4), pp. 179193. doi: 10.1016/j.aucc.2016.08.002.

Mitchell, M. L. et al. (2017) 'A family intervention to reduce delirium in hospitalised ICU patients: A feasibility randomised controlled trial', Intensive and Critical Care Nursing. Elsevier Ltd, 40, pp. 77-84. doi: 10.1016/j.iccn.2017.01.001.

Mitchell, M. L. and Courtney, M. (2004) 'Reducing family members' anxiety and uncertainty in illness around transfer from intensive care: An intervention study', Intensive and Critical Care Nursing, 20(4), pp. 223-231. doi: 10.1016/j.iccn.2004.05.008.

Noome, M. et al. (2016) 'Exploring family experiences of nursing aspects of end-of- life care in the ICU: A qualitative study', Intensive and Critical Care Nursing. Elsevier Ltd, 33, pp. 56-64. doi: 10.1016/j.iccn.2015.12.004.

Pochard, F. et al. (2005) 'Symptoms of Anxiety and Depression in family members of intensive care unit patients before discharge or death', Journal of critical care medicine, 20(1), pp. 90-96.

Schubart, J. R. et al. (2015) 'ICU family communication and health care professionals: A qualitative analysis of perspectives', Intensive and Critical Care Nursing. Elsevier Ltd, 31(5), pp. 315-321. doi: 10.1016/j.iccn.2015.02.003.

Shelton, W. et al. (2010) 'The effect of a family support intervention on family satisfaction, length-of-stay, and cost of care in the intensive care unit.', Critical care medicine, 38(5), pp. 1315-1320. doi: 10.1097/CCM.0b013e3181d9d9fe.

Turner, M. et al. (2015) 'The assessment of parental stress and support in the neonatal intensive care unit using the Parent Stress Scale - Neonatal Intensive Care Unit', Women and Birth. Australian College of Midwives, 28(3), pp. 252-258. doi: 10.1016/j.wombi.2015.04.001.

Wetzig, K. and Mitchell, M. (2017) 'The needs of families of ICU trauma patients: an integrative review', Intensive and Critical Care Nursing. Elsevier Ltd, 41, pp. 63-70. doi: 10.1016/j.iccn.2017.02.006.

Wintermann, G.-B. et al. (2016) 'Predictors of posttraumatic stress and quality of life in family members of chronically critically ill patients after intensive care', Annals of Intensive Care. Springer Paris, 6(1), p. 69. doi: 10.1186/s13613-016-0174-0.

Yousefi, H. et al. (2012) 'Effectiveness of nursing interventions based on family needs on family satisfaction in the neurosurgery intensive care unit.', Iranian journal of nursing and midwifery research, pp.
296-300. 